\title{
Anti-hyperglycemic Effect and Regulation of Carbohydrate Metabolism by Phenolic Antioxidants of Medicinal Plants against Diabetes
}

\author{
HP Gajera* and Darshna G Hirpara \\ Department of Biotechnology, College of Agriculture, Junagadh Agricultural University, India
}

Submission: January 09, 2018; Published: February 01, 2018

*Corresponding author: HP Gajera, Department of Biotechnology, College of Agriculture, Junagadh Agricultural University, Junagadh-362 001, India, Email: harsukhgajera@yahoo.com

\section{Introduction}

Diabetes mellitus is a carbohydrate metabolism disorder of endocrine system due to an absolute or relative deficiency of insulin secretion, action, or both [1]. The disorder affects more than 100 million people worldwide and it is predicted to reach 366 million by 2030. The non-insulin dependent diabetes mellitus (NIDDM, type 2) is the most prevalent form globally which is associated with elevated postprandial hyperglycemia. The occurrence of NIDDM 2 has been shown an alarming increase during the last decade (http//www.who.Int/diabetes/en/).

Plant derivatives with reported hypoglycaemic properties have been used in folk medicine and traditional healing systems. Very few of these traditional antidiabetic plants have received proper scientific or medical scrutiny despite recommendations by WHO. Ayurveda and other Indian traditional approaches have described more than 800 plants in the Indian subcontinent, known to possess antidiabetic potentials. These require to be effectively studied and in fact only few of them have been characterized for their mechanistic action [2,3]. Pancreatic $\alpha$-amylase, is a key enzyme in the digestive system and catalyses the initial step in hydrolysis of starch to maltose and finally to glucose. Degradation of this dietary starch proceeds rapidly and leads to elevated post prandial hyperglycemia. It has been shown that activity of HPA in the small intestine correlates to an increase in post-prandial glucose levels, the control of an important aspect in treatment of diabetes [4]. Hence, retardation of starch digestion by inhibition of enzymes such as $\alpha$ - amylase would play a key role in the control of diabetes.

The discovery of specific high-affinity inhibitors of pancreatic $\alpha$-amylase for the development of therapeutics has remained elusive. Inhibitors currently in clinical, use for example, acarbose, miglitol, and voglibose, are known to inhibit a wide range of glycosidases such as $\alpha$-glucosidase and $\alpha$-amylase. Because of their non specificity in targeting different glycosidases, these hypoglycemic agents have their limitations and are known to produce serious side effects. Therefore, the search for more safer, specific, and effective hypoglycemic agents has continued to be an important area of investigation with natural extracts from readily available traditional medicinal plants offering great potential for discovery of new antidiabetic drugs [5]. Ponnusamy et al. [6] studied on antidiabetic medicinal plants for human pancreatic amylase inhibitory effect in vitro and found that pancreatic $\alpha$-amylase lower the levels of post perandial hyperglycemia via control of starch breakdown. The probable mechanism of action of the above fractions is due to their inhibitory action on HPA, thereby reducing the rate of starch hydrolysis leading to lowered glucose levels. Phytochemical analysis revealed the presence of alkaloids, proteins, tannins, cardiac glycosides, flavonoids, saponins and steroids as probable inhibitory compounds.

\section{Anti-hyperglycemic effect of natural phenolic antioxidants}

Advanced molecular studies showed that methanol extract of black jamun plant modulate the expression of glucose transporter (Glut-4), peroxisome proliferator activator receptor gamma (PPAR $\gamma$ ) and phosphatidylinositol-3-kinase (PI3 kinase) comparable with insulin and rosiglitazone [7]. Evaluation of black jamun containing antidiabetic poly herbal formulation in alloxan induced diabetic rats also showed significant hypoglycemic activity, positive glucose tolerance activity and reduced lipid peroxidation in various organs compared to that of the diabetic control animals [8]. Meshram et al. [9] studied on hypoglycaemic action of black jamun seeds. The possible 


\section{Current Research in Diabetes \& Obesity Journal}

mechanism by which extracts bring about its may be by affecting the activity of glucoamylase or by increasing the glycogen biosynthesis. Thus, the significant inhibition of glucoamylase suggests that the active hypoglycaemic compound present in methanolic extracts of jamun seeds does not necessarily require the presence of functioning of $\beta$-cells for its favourable action seen in type-I. It means the methanol extracts of black jamun seeds may act in a variety of diabetic conditions with or without functioning of pancreatic $\beta$-cells.

Hasan et al. [10] studied DPPH radical scavenging activity of black jamun seed extracted in methanol. It has been determined that the antioxidant effect of plant products is mainly due to radical scavenging activity of phenolic compounds such as flavonoids, polyphenols, tannins, and phenolic terpenes [11]. Liang \& Yi [12] identified hydrolysable tannins (ellagitannins) extracted from black jamun fruit showed a very good DPPH radical scavenging activity and ferric reducing/antioxidant power. The results are promising and indicating the utilization of the fruit of black jamun as a significant source of natural antioxidants.

Stanely et al. [13] evaluated the protective effects of gallic acid on brain lipid peroxidation products, antioxidant system, and lipids in streptozotocin induced type II diabetes mellitus. The results showed the beneficial effects of gallic acid on brain metabolism in streptozotocin induced type II diabetic rats. A diet containing gallic acid may be beneficial to type II diabetic patients. Meguro et al. [14] investigated the effects of continuous ingestion of a catechin rich beverage in patients with type 2 diabetes. The significant increase in insulin level was observed to patients fed with green tea containing the catechin. Rizvi et al. [15] evaluated the effect of tea catechins (epigallocatechin gallate (EGCG), epigallocatechin (EGC), epicatechin gallate (ECG) and epicatechin (EC)) on markers of oxidative stress in erythrocytes from type 2 diabetics. The relative effectiveness of individual catechins are in the order of EGCG>ECG>EGC>EC. Higher intake of catechin rich food by diabetic patients may provide some protection against the development of long term complications of diabetes. Chlorogenic acid is a major component of coffee that may provide more of an explanation for coffee's effect on risk for type 2 diabetes. Chlorogenic acid proposed beneficial effects on glucose metabolism. The chlorogenic acid may delay glucose absorption in the intestine through inhibition of glucose-6-phosphate translocase 1 and reduction of the sodium gradient driven apical glucose transport. In vitro studies and animal studies showed that chlorogenic acid derivates can be decreased hepatic glucose output through inhibition of glucose6-phospatase [16].

Jung et al. [17] investigated the blood glucose lowering effect and antioxidant capacity of caffeic acid in mice. Caffeic acid induced a significant reduction of the blood glucose and glycosylated hemoglobin levels than the control group. Increased plasma insulin by caffeic acid was attributable to an antidegenerative effect on the islets. Caffeic acid also markedly increased glucokinase activity and its mRNA expression and glycogen content and simultaneously lowered glucose-6phosphatase and phosphoenol pyruvate carboxykinase activities and their respective mRNA expressions, accompanied by a reduction in the glucose transporter 2 expression in the liver. Zhi et al. [18] investigated the antioxidant activity of black jamun leaf extracts. Leaf extracts contained phenolic compounds, such as ferulic acid and catechin, responsible for their antioxidant activity.

Diabetes, when uncontrolled, causes dyslipidemia often followed by atherogenic abnormalities. Balasubashini [19] examined role of ferulic acid (flavonoid) in diabetes induced dyslipidemia. Study demonstrates that ferulic acid lowers the lipid levels in diabetic rats and hence prevents further complications. It has been documented that ferulic acid may lower blood sugar level of Type 1 and Type 2 diabetic mice by enhancing insulin secretion [20]. Diabetic mice was given rice derived ferulic acid for 17 days and results showed that plasma insulin level increased while blood sugar level decreased significantly compared with control [21]. Ferulic acid may be beneficial in Type 2 diabetic and for the management of diabetic complications. Hussain et al. [22] indicated that quercetin can decrease postprandial glucose level after disaccharides loading, which may be mainly attributed to inhibition of $\alpha$-glucosidase as one of the expected mechanisms for the reduction of plasma glucose. This effect subsequently leads to suppression of postprandial hyperglycemia. Thus, quercetin can be considered as a potential candidate for the management of type 2 diabetes mellitus. Medicines that reduce postprandial hyperglycemia by suppressing the absorption of carbohydrates are shown to be effective for prevention and treatment of non-insulin dependent diabetes mellitus [23]. Quercetin inhibited in vitro the intestinal $\alpha$-glucosidase activity [24]. It has been also assumed that quercetin activates tyrosine kinase. Phosphorylation of the specific region of the subunit in insulin receptor (including Tyr1158, Tyr-1161 and Tyr-1162) correlates with receptor tyrosine kinase activation and the propagation of the biological actions of the hormone [25].

\section{Correlations between antidiabetic, antiradical and phenolic compounds}

Our previous study Gajera et al. [26,27] suggested that antidiabetic activity of fruit parts of black jamun landraces was positively correlated with free radical scavenging activity, nutraceuticals profile and individual phenolic constituents. Total phenols and individual phenolics are positively correlated with antidiabetic and antiradical activities but vary with different level of significances. Individual phenolics - gallic, catechin, ellagic and ferulic acids are highly positively correlated $\left(\mathrm{P}_{0.001}\right)$ with antidiabetic and free radical scavenging activity. The positive correlation $\left(\mathrm{P}_{0.01}\right)$ was established for caffeic and chlorogenic acids to scavenge free radicals and $\alpha$ amylase inhibitory activity 


\section{Current Research in Diabetes \& Obesity Journal}

(antidiabetic) for methanolic extract of black jamun fruit parts. The quercetin was found only in seed and its part kernel fraction of BJLR-6 (very small size fruits) and found to be positively correlated $\left(\mathrm{P}_{0.05}\right)$ with antidiabetic activity. Among the fruit parts of black jamun land races, seed exhibited maximum seven individual phenolics and total phenols, particularly in their kernel parts. Among the individual phenolics, gallic acid was most diverse phenolic constituents which significantly positively correlated $\left(\mathrm{P}_{0.001}\right)$ with inhibition of $\alpha$ amylase activity and DPPH radical scavengers followed by catechin, ellagic and ferulic acids in different fruit parts of black jamun land races. The study explained correlation of individual phenolics including flavonoids (ferulic) with $\alpha$ amylase inhibition and free radical scavenging activities in fruit parts of indigenous black jamun landraces.

Muniappan et al. [28] reviewed the black jamun as an antidiabetic plant which contained ellagic acid, glycosides, anthocynine, kampferol, marcein and isoquarcetine; and halt the diastolic conversation of starch into sugar. The phenolic constituents may be contributed directly to the antioxidative action. Consequently, the antioxidant activities of plant/ herb extracts are often explained by their total phenolics and flavonoid contents with good correlation.

\section{References}

1. Alberti KG, Zimmet PZ (1998) Definition, diagnosis and classification of diabetes mellitus and its complications. Part 1: diagnosis and classification of diabetes mellitus. Diabet Med 15(7): 539-553.

2. Grover J, Vats V, Rathi S (2000) Anti-hyperglycemic effect of Eugenia jambolana and Tinospora cordifolia in experimental diabetes and their effects on key metabolic enzymes involved in carbohydrate metabolism. J Ethnopharmacol 73(3): 461-470.

3. Mukherjee P, Maiti K, Mukherjee K, Houghton PJ (2006) Leads from Indian medicinal plants with hypoglycaemic potentials. Ethnopharmacol 106(1): 1-28.

4. Eichler H, Korn A, Gasic S, Pirson W, Businger J (1984) The effect of a new specific $\alpha$-amylase inhibitor on post-prandial glucose and insulin excursions in normal and Type 2 (non-insulindependent) diabetic patients. Diabetologia 26(4): 278-281.

5. Patwardhan B, Vaidya D, Chorghade M (2004) Ayurveda and natural products drug discovery. Current Science 86(6): 789-799.

6. Ponnusamy S, Ravindran R, Zinjarde S, Bhargava S, Kumar A (2010) Evaluation of traditional indian antidiabetic medicinal plants for human pancreatic amylase inhibitory effect in vitro. Evid Based Complement Alternat Med.

7. Anandharajan R, Jaiganesh S, Shankernarayanan N, Viswakarma $\mathrm{R}$, Balakrishnan A (2006) In vitro glucose uptake activity of Aegles marmelos and Syzygium cumini by activation of Glut-4, PI3 kinase and PPAR. Phytomedicine 13(6): 434-441.

8. Joshi C, Priya E, Venkataraman S (2007) Hypoglycemic and antilipidperoxidative effects of a polyherbal formulation, Diakyur, in experimental animal models. Journal of Health Sciences 53(6): 734739.

9. Meshram G, Yadav S, Dattatraya S, Patil B, Singh D (2011) Antibacterial study and effect of ethanolic extracts of Syzygium cumini seeds powder on glucoamylase in vitro. J Pharm Sci \& Res 3(2): 1060-1063.
10. Hasan R, Mokarram M, Raushanara A, Mariam J, Ehsanul H, et al. (2009) DPPH free radical scavenging activity of some Bangladeshi medicinal plants. Journal of Medicinal Plants Research 3(11): 875-879.

11. Rahman MA, Moon SS (2007) Antioxidant polyphenol glycosides from the Plant Draba nemorosa. Bulletin of the Korean Chemical Society 28(5): 827-831.

12. Liang LZ, Yi ML (2009) Antioxidant tannins from Syzygium cumini fruit. African Journal of Biotechnology 8(10): 2301-2309.

13. Stanely Prince M, Kumar MR, Selvakumari CJ (2011) Effects of gallic acid on brain lipid peroxide and lipid metabolism in streptozotocininduced diabetic Wistar rats. J Biochem Mol Toxicol 25(2): 101-107.

14. Meguro S, Nagao T, Hase T, Otsuka K, Komikado M, et al. (2009) A catechin-rich beverage improves obesity and blood glucose control in patients with type 2 diabetes. Obesity (Silver Spring) 17(2): 310-317.

15. Rizvi SI, Zaid MA, Anis R, Mishra N (2005) Protective role of tea catechins against oxidation-induced damage of type 2 diabetic erythrocytes. Clin Exp Pharmacol Physiol 32(1-2): 70-75.

16. Van Dam RM (2006) Coffee and type 2 diabetes: from beans to betacells. Nutr Metab Cardiovasc Dis 16(1): 69-77.

17. Jung UJ, Lee MK, Park YB, Jeon SM, Choi MS (2006b) Antihyperglycemic and Antioxidant Properties of Caffeic Acid in db/db Mice. J Pharmacol Exp Ther 318(2): 476-483.

18. Ruan ZP, Zhang LL, Lin YM (2008) Evaluation of the antioxidant activity of Syzygium cumini leaves. Molecules 13(10): 2545-2556.

19. Balasubashini M, Rukkumani R, Menon V (2003) Protective effects of ferulic acid on hyperlipidemic diabetic rats. Acta Diabetol 40(3): 118122.

20. Nomura H (2001) Acceleration of ferulic acid and related compounds on insulin secession. Research report of Wakayama industrial technology center, pp. 17-19.

21. Jung EH, Kim SR, Hwang IK, Ha TY (2006a) Hypoglycemic effects of a phenolic acid fraction of rice bran and ferulic acid in C57BL/KsJ-db/db mice. J Agric Food Chem 55(24): 9800-9804.

22. Hussain SA, Ahmed ZA, Mahwi TO, Aziz TA (2012) Quercetin dampens postprandial hyperglycemia in type 2 diabetic patients challenged with carbohydrates load. International Journal of Diabetes Research 1(3): $32-35$.

23. McCune L, Johns $T$ (2002) Antioxidant activity in medicinal plants associated with the symptoms of diabetes mellitus used by the indigenous peoples of the North American boreal forest. Ethnopharmacol 82(2-3): 197-205.

24. Jo SH, Ka EH, Lee HS, Apostolidis E, Jang HD, et al. (2009) Comparison of antioxidant potential and rat intestinal $\alpha$-glucosidases inihibitory activities of quercetin, rutin, and isoquercetin. International journal of applied research in natural products 2(4): 52-60.

25. Rosen OM (1987) After insulin binds. Science 237(4821): 1452-1458.

26. Gajera HP, Gevariya Shila N, Hirpara Darshna G, Patel SV, Golakiya BA (2017) Antidiabetic and antioxidant functionality associated with phenolic constituents from fruit parts of indigenous black jamun (Syzygium cumini L.) landraces. J Food Sci Technol 54(10): 3180-3191.

27. Gajera HP, Gevariya Shila N, Patel SV, Golakiya BA (2018) Nutritional profile and molecular fingerprints of indigenous black jamun (Syzygium cumini L.) landraces. Journal of Food Science and Technology 55(2): 730-739.

28. Ayyanar M, Subash Babu P (2012) Syzygium cumini (L.) Skeels: A review of its phytochemical constituents and traditional uses. Asian Pac J Trop Biomed 2(3): 240-246. 

(C) Commons Attribution 4.0 Licens

DOI: 10.19080/CRDOJ.2018.05.555668
Your next submission with Juniper Publishers will reach you the below assets

- Quality Editorial service

- Swift Peer Review

- Reprints availability

- E-prints Service

- Manuscript Podcast for convenient understanding

- Global attainment for your research

- Manuscript accessibility in different formats

( Pdf, E-pub, Full Text, Audio)

- Unceasing customer service

Track the below URL for one-step submission https://juniperpublishers.com/online-submission.php 